\title{
Oral Sources: A Reflection of contemporary Nepalese society $^{1}$
}

\author{
Prof. Dr. Ghanashyam Bhattarai"
}

\section{What is history?}

History can simply be defined that it is a comprehensive study of the past events and also the account of human deeds. Carr defined history as 'an unending dialogue between past and present." (E.H.Carr, 1999) Hence every event and the activities of the contemporary society are largely guided by the deeds of the past. Social development is a continuous process and in this process history plays a major role. There is the connection between the past and present.

Cubitt define history just as the collective memory. He also emphasize that it is the form of intellectual discipline, and the type of knowledge, through which a given society is able to remember. (Cubitt, 2007) In the word of Peter Burke 'history is a social memory', Patrick Hutton accept 'history as an art of memory'. (Cubitt, 2007) For Ludmilla Jordanova, 'the writing of history is about the transmission of memories'; indeed, 'the practice of history is, after all, a highly specialized form of commemoration'. (Jordanova, 2000)

From the above definition we can sum up that history is a detail account of human beings and the society where he resides. All the activities of the people are recorded as history which encompasses all human deeds. And history originated from the evidences that were transmitted from generation to generation by words of mouth.

\section{Sources of History}

No historical study is possible without evidences. By studying history we learn about the past and prospect for the future. We are ignorant about many aspects of the past because of lack of records due to the loss of such records. History of certain place is constructed with the utilization of various sources. Such sources can be written or unwritten.

* Central Department of History, TU

1 This is the article based on paper presented in the seminar organized by Central Department of Sociology with collaboration of Chaitanya Mishra Foundation held on 5/28/2017 
Non-written sources are remains, buildings, artifacts, coins, statues, clothing and songs and written ones like records, diaries, newspapers and treaties. History consists of a corpus of ascertained facts. The facts are available to the historian in documents, inscriptions and so on, like fish on the fish monger's slab. The historian collects them, takes them home, and cooks and serves them in whatever style appeals to him. (E.H.Carr, 1999) But not only written records but also unrecorded evidences deposited in the human minds are important in history writing. As Gottschalk says, "every man is his own historian." (Gottschalk, 1954)

The historian can rediscover what has been completely forgotten, in the sense that no statement of it has reached him by an unbroken tradition from eyewitnesses. He can even discover what, until he discovered it, no one ever knew to have happened at all. This he does partly by the critical treatment of statements contained in his sources, partly by the use of what are called unwritten sources, which are increasingly employed as history becomes increasingly sure of its own proper methods and its own proper criterion. (Collingwood)

Though most of the modern historians preferred written sources for constructing history as they are more reliable and valid evidences, unwritten sources are also equally important. In fact, all the past deeds and activities of the human beings are the sources of history. As Collingwood says, "In scientific history anything is evidences which are used as evidence, and no one can know what is going to be useful as evidence until he has had occasion to use it." (Collingwood, 1992).

As an American writer Frederich Jackson Turner says, "All the remains left by the people from centuries are the sources of history. They may be in written form or in the form of language, art, tradition, architect, numismatics, inscription, chronicles, potteries, pyramid, literature, and so on." (Stern, 1970)

\section{Oral History/Oral Source}

Oral history is 'the collection of information from old people that does not feature in the textbooks, yet it is an essential process in compiling local history'. Oral history continues to be an important means by which non-academics can actively participate in 'making history'. However practitioners across a range of academic disciplines have also developed the method into a way of recording, understanding and archiving narrated memories.

Among the various kinds of historical sources oral sources occupy a special place. Oral history involves the collection, analysis and study of various historical facts and information about events, families or even individuals. They are messages, but unwritten; their preservation 
entrusted to the memories of successive generations of people. For centuries the use of oral sources in understanding the past is a general phenomenon in history writing. Oral history is 'the first kind of history' (Thompson, 1978) which is mainly focused on the making history of the common people.

"Ancient things are today." This proverb is popular in Ghana. Oral traditions are documents of the present, because they are told in the present. They also embody a message from the past, so they are expressions of the past at the same time. They are the representation of the past in the present.

The sources of oral historians are reminiscences, hearsay, or eyewitness accounts about events and situations which are contemporary, that is, which occurred during the lifetime of the informants. (Vansina, 1985) News, eyewitness, hearsay, reminiscence, verbal art (poems and poetry, songs, sayings, proverbs, and tales), traditions and customs, memorized speeches, historical gossips, epics, etc. are the major oral sources of history.

Among the many oral sources memory is one of the significant sources of history. Memory is the core of oral history, from which meaning can be extracted and preserved. Simply put, oral history collects memories and personal commentaries of historical significance through recorded interviews. Oral history is as reliable or unreliable as other research sources. No single piece of data of any sort should be trusted completely, and all sources need to be tested against other evidence. (Ritchi, 2003)(26)

Oral reminiscence and oral traditions are two major sources of oral history. Oral reminiscence is the first hand recollection of people interviewed by a historian. Oral tradition is the narratives and descriptions of people and events in the past which have been handed down by word of mouth over several generations. (John Tosh, 206)

In every society people's belief, traditions, values, customs have enormous impact on their politics, social development and literature. All these are the product of the society and also represent the respective society. Therefore, oral sources are equally important to study the human society similar to the science, sociology, anthropology and archeology. Ironically, many of the written sources cited by today's historians were themselves oral in origin. We can cite here "Dibyoupadesh of Prthivinaraya Shah" as an example. This manuscript was originally not a written document. It was the directives given by the King P.N. Shah to the civil-military officials of Gorkha Kingdom. This manuscript was come into written form only during the reign of King Rajendra Bikram Shah. 


\section{Importance of Oral Sources in history}

Oral sources have great importance in history. It is the way of capturing the disappearing traditions of the countryside. Remaking the oral history we can transfer our rich cultural and social traditions to the next generations. Oral history can give a voice to individuals and groups who are sometimes marginalized in 'conventional' histories - the working classes, women and ethnic minorities, for instance. It can provide new information, alternative explanations and different insights which are potentially of enormous value. The spoken word can convey feelings and emotions with immediacy and an impact that the written word cannot match, as well as preserving a record of local dialects and accents. It allows the historian to ask questions of his or her informant - to be present at the creation of a historical source, rather than relying solely on those created by others.

Oral history has been enlarging the scope of recent social and cultural history. It always contributes to incorporate the voice of the common people in the written history. It helps to reveal the socio-cultural, economic and political aspects of that group of people or community whose history is not recognized by the historians.

It is the oral sources through which any researcher can explain and analyze the local history. From the local history the national character of the history can be established. Every society has unique culture and tradition, and the differences can also be found in different geographical location even in the same culture and tradition. Such uniqueness and dissimilarity can be understood only through oral sources. Oral source is also useful to study the evolution of human being from the anthropological perspective.

It also helps to develop many social theories. For example, the history of gender concerns the changing contours of male dominance over time, as well as the subjugation of women. Both men's social power and their 'masculine' qualities can only be apprehended as aspects of a gender system: neither 'natural' nor constant, but defined by a shifting relation to the feminine. (Tosh, 1991)

\section{Use of oral source in Nepalese history writing}

Nepal is rich in oral sources. Various types of oral source are exist in Nepal like, folklore, folk music, folk dance, folk drama, legends and traditions, oral stories, memoirs etc. The impact of people's belief, tradition, culture and religion could also be seen in the society, literature and politics of any country. These are the heritages preserved by ancestors to their successors. With the help of these sources upcoming generation better know and understand the situation of the past society, tradition and culture. These sources importantly help historians to study and analyze the development process of a particular society and culture. 
For a long time in Nepal information disseminated through inscriptions, chronicles, manuscripts and artifacts were acknowledged as history. History is not only the collection of facts but also the comprehensive analysis of the events and its repercussion that experienced in multi-sectoral aspects of the society.

Nepal is rich in tradition, culture, beliefs, and traditional ethics and values. The massages hidden into these sources represent the contemporary Nepali society. People express their sorrow, grief and torture given by the family, society or state by singing their own song, creating oral stories, dancing in festivals, etc.

Indeed, oral sources are the reflection of our society. But such reflections are not clearly visible rather blurred. It is the historians who skillfully unfold the real picture of the society and reconnect it with the national history.

There are very few references of using oral sources for recreating Nepali history. Almost all historians had used 'King P.N. Shah's Upadesh' as written source. Actually it was not a written source but an oral source. It was a directive given to the officials by the King.

Brian Hodgson has extensively collected and used oral sources in his writings. His work on Nepali judiciary system was mainly based on interview with local people. (Hodgson, 1880).

No any inscriptional evidence has been found so far to shade the light on the history of preLicchavi Period of Nepal. Whatever has been known about that period is only through oral sources. Chronicles were the main source of information about the history of pre-Licchavi era. 'Kirat Mundhum' was the only major source to know about the Kirat regime.

From the early times Nepalese administration and social system has been largely dominated by the Hindu text (Shastras). Evern today, many of the legal codes are based on Hindu Shaastras. All these Hindu texts were originally the recollection of the events which were scripted in later period. Shruti means 'listening' or 'hearing', and smritis, which means 'that are remembered'. The examples of shruti are the Vedas and the Upanishads where as examples of smriti include the Mahabharata, the Ramayana, the Manusmriti, etc.

In recent time, the practice of using oral sources in history writing is gradually increasing. Some western researchers, who are interested in ethnic and medieval socio-cultural history of Nepal, have been carrying their research work on the basis of oral sources.

John Hitchcock in an article published in 1974 discussed the evolution of caste organization in Nepal in light of Tucci's investigations of the Malla Kingdom of Western Nepal. It 
was largely based on oral sources. Also the Walter F. Winkler conducted a research work on the evolution of Thakuri political authority of western Nepal was primarily based on oral sources. To study the caste organization of Nepalese society researcher must depend upon the oral sources rather than written. Winkler's study has extensively used many oral historical resources such as family and lineage histories, orally transmitted genealogies, heroic songs, legendary accounts and myths and their importance to understanding the evolution and regional definition of caste organizations in Nepal. (Winkler, 1984) Daniel 'Wright's' History of Nepal, was also based on oral source.

Martin Gaenszle has extensively used oral sources to study the socio-cultural context of Mewahang Rai of east Nepal in his book "Ancestral Voices: Oral ritual texts and their social contexts among the Mewahang Rai of east Nepal”.

History as Mindscapes: A Memory of the Peasants Movement of Nepal, By Yogesh Raj is another historical text mainly based on the memoirs of a peasant leader Krishna Bhakta Caguthi, a Newar native from Bhaktapur and member of the Jyapu community. It gives a rich account of social and agrarian relations of the period, with a number of accurate details, as well as valuable observations concerning the local peasant movements in Nepal.

The folklore stories of Balabhadra, the legendary hero of the Anglo-Nepal War, and Bhrikuti, second queen of Tibetan Emperor Tsrong Tsong Gampo, are good example of folklore that may tell much about the history of bravery, patriotism, cultural exchange and exchange of art in this Himalayan kingdom.

\section{Memoirs as source of History}

From ancient times, many visitors made journey to Nepal. Nepal has inspired several personal accounts, some of them very scholarly, and some quite personal. Such personal memoires an account also offers many historical facts to the historians. Colonel William Kirkpatrick's 'An accounts of the kingdom of 'Nepaul.', the first Finnish tourist Marshall Mannerheim's memoir of hunting trips to Nepal titled "Marshall and The Maharajah, A Short History of Nepalese Tourism, William Tayler's Memoirs of William Tayler, MP Koirala's A Role in Revolution, Sirdar Bhim Bahadur Pandey's Tyas Bakhat ko Nepal in five volumes, Atmabrittant and Jail Journal by: Bishweshwor Prasad Koirala, Kamal Tuladhar's Caravan to Lhasa: Newar Merchants of Kathmandu in Traditional Tibet, are some of the important memoires which reveals the various aspects of Nepali history of the contemporary times. 
One of the memoir written by Narayan Subedi entitled, "100 Din: Maobadi Kabjama" is a memoir of author that was written during he was in moist imprisonment of a hundred days. This book is a testimony of his undergo of pain, fear and terror. Same kinds of memoirs were also produced by Maoist combatants viz. Ganga Shrestha's memoir, Gadhidarbardekhi Si hadarbarsamma,Surul Pun Magar's Andhisanga Khelda, Tara Kumari's Chapamar Yubatiko Dayari.

\section{Some Nepalese oral traditions}

All the traditions, hearsay, idioms, proverbs and folklore carry the historical facts of Nepalese society. There is a popular hearsay- "Sati ko shraap pareko desh", meaning 'there would not be true judgment of the honesty, devotion and sacrifice of the people in the country, instead honesty and devotion always be penalized. 'Another sayings of Nepalese society is, "Budha mare bhasha sare', meaning language, culture, traditions all are transfer from predecessor to successors.

We have also the tradition of not visiting to Budhanilkanth by any ruling king due to some superstitious belief, but such sayings cannot be proved by any written source. Similarly, the account of the war between Aramudi and Jayapeed (king of Kashmir) on the bank of Kaligandaki River was mentioned only in Rajtarangini of Kalhana that cannot be verified by other sources.

In our society there is a tradition of 'Kul devata or devi' (family God and Goddesses), but no one knows about the origin of such tradition in the family. Such cultural diversity can be studied only through oral sources.

Teej songs are very popular in Nepalese society. Such songs reflect the very gloomy picture of our society where female members of the family are facing atrocity from the female. Women atrocities by the women and domination of the male member are the common characters of Nepalese society.

In western Nepal 'Gaine geet' - songs of Gandharva people, is very popular. In the past Gandharva had played a very significant role to disseminate the information of national importance, like natural calamities, war, major events of the country and society and so on, to the common people. Indeed, they were the messengers who were conveying the messages through songs with sarangi. Their narratives are either based on the classical and local myths like Pashupati, Gorakhanath or the legends related to historical personalities, which include Kings, prime ministers and famous fighters of the country; such as Prithiwi 
Narayan Shah, Madan Kirti Shah, Amar Singh, Bhakti Thapa, Balabhadra, Jung Bahadur, Chandra Shamsher, and Juddha Shamsher. Gandharvas also perform tragic ballads like Sarumai Rani, and recite narratives composed known locally as Sabai and Ghatana. Sabai is also popular among the Nepali speaking communities in a semi literary form. It describes tragic events such as wars, earthquakes or floods, as well as the deeds of heroes. The Bhotko Ladainko Sabai which describes the war in 1854 between Nepal and Tibet was published in 1855 and remains very popular to date. (Tulsi Diwas, 2007)

'Khando Jagaune' is another unique tradition of Khasa people of Nepal that observed during the marriage ceremony. It is one of the rituals of marriage system to exhibit the bravery and valor of the Gorkhali people.

We have abundance of cultural dance, songs and traditions in every ethnic society. Heterogeneity of Nepalese society is the assets of our country in which one can experience variety of culture and tradition through which the socio-economic and cultural history of that particular ethnic people could be studied. Our folklore developing as oral tradition represents the ethnic culture, tradition and social values, education as well as social evils and belief of our society. (Gnyawali, 5.2063)

\section{Shortcomings of Oral Sources}

Modern historians do not totally agree that oral sources are reliable for exploring historical facts. Sometimes it might mislead them about the facts. Several socio-cultural traditions have been changing in due course of time and space. If a historian is ignorant with this changing nature and phenomena of society and culture he/she could not able to discover the hidden historical aspects of the society. Hence, historian must be skillful and be familiar with the social environment and social content to obtain the real picture of the society.

\section{Conclusion}

Oral sources are alternative historical source of the historians. It largely contributes to reveal many aspects of the society after entering into the depth of the society and culture. History studies the human development and progress. History of the mankind is developed through human culture and traditions. Human history is always reflecting on the oral sources. If such sources are preserved and analyzed with the appropriate approach and techniques we can enrich not only our history but also the culture, society and human beings. 
It is better to conclude this paper with the remark of Tosh on oral history that 'oral history promises a sense of place and community accessible to ordinary people, while at the same time illuminating broader features of social history." (Tosh, 1991)

\section{Bibliography}

Collingwood, R. (1992). The Idea of History. Madras: Oxford University Press.

Cubitt, G. (2007). History and Memory. London: Manchester Universtiy Press.

E.H.Carr. (1999). What is History? New Delhi: McMillon.

Gnyawali, H. L. (5.2063). Gulmeli Lokgeetma Pratibimbit Samaj. Madhuparka, 100-103. Gottschalk, L. (1954). Understanding History. New York: University of Chicago.

Hodgson, B. H. (1880). Miscellanious Essays Relating to Indian Subjects, Vol. 2. London: Trubner \& Co.

Jordanova, L. (2000). History in Practice. London.

Ritchi, D. A. (2003). Doing Oral History, A Practical Guide, 2nd edition. New York: Oxford .

Stern, F. (1970). Varities of History. New Delhi: Mac Millon.

Thompson, P. (1978). The Voice of the Past: Oral History. New York: Oxford University Press.

Tosh, J. (1991). The Pursut of History. London: Longman .

Tulsi Diwas, C. B. (2007). The Intangible Cultural Heritage of Nepal: Future Directions. Kathmandu: UNESCO office.

Vansina, J. (1985). Orat Tradition as History. London: The Universtiy of Winsconsin Press. Winkler, W. F. (1984). Oral History and the Evolution of Thakuri Political Authority in A Subregion of Far Western Nepal. Himalaya, the Journal of the Association for Nepal and Himalayan Studies, Vol. 4, No. 2. 